\title{
The Politics of Legitimacy and Force in \\ INTERNATIONAL RELATIONS: VITORIA AND RAWLS ON THE 'LaW of Peoples' and the Recourse to WaR ${ }^{*}$
}

\author{
La politica de la legitimidad y la fuerza en las relaciones \\ internacionales: Vitoria y Rawls sobre el "Derecho de Gentes" \\ y el recurso de la guerra
}

\section{LUIS VALENZUELA-VERMEHREN}

Universidad Católica de Temuco

\begin{abstract}
This article confronts two philosophical positions that define the nature of international order in matters concerning state legitimacy and the justifications for the recourse to war. The first position, set forth by Francisco de Vitoria in the sixteenth century, frames legitimacy and the use of force within the traditional, Christian natural law conception of justice. Legitimate are those states that uphold universal principles of justice, not the political principles of a particular regime form, while the recourse to war is likewise justified by the constitutive tenets of the ius ad bellum and the ius in bello. By contrast, Rawls' Law of Peoples, which compares itself to the Christian natural law tradition, articulates nonetheless a particular liberal conception of justice that defines legitimacy in wholly political terms. In addition, in its appeal to the so-called 'supreme emergency exemption' the Rawlsian Law of Peoples dispenses with a crucial aspect of the traditional ius in bello that prohibits the targeting of civilian populations, as an exceptional means for defending and promoting a liberal international order. It is argued that such an ideologically based view of order posits a non-inclusive conception of justice in a culturally and politically diverse world and, hence, encourages conflict, resistance and strife between liberal and non-liberal states, and even strengthens autocratic government beyond the liberal zone of peace. A more tolerant and sound view, held by Terry Nardin's conception of 'common morality', is similar to Vitoria's traditional conception of a more politically tolerant justice-based order and expresses in contemporary ethical language the principal tenets of the tradition of the laws of war set forth by Vitoria himself.
\end{abstract}

Key words: Normative international theory, John Rawls, Francisco de Vitoria, international politics, international law.

\section{RESUMEN \\ Este artículo compara dos posturas filosóficas que definen la naturaleza del orden internacional en materia de legitimidad estatal y las justificaciones para el recurso a la guerra. La primera posición, establecida por Francisco de Vitoria en el siglo XVI, plantea los marcos de legitimidad y el uso de la fuerza dentro de la concepción tradicional cristiana del derecho natural y la justicia. Legítimos son aquellos estados que respetan los principios universales de justicia, sin}

* I wish to thank the two anonymous reviewers for their insightful comments and observations on this manuscript. 
importar el régimen específico de éstos. Asimismo, el recurso a la guerra sólo encuentra su justificación en los principios constitutivos del ius ad bellum y el ius in bello. El Derecho de Gentes de Rawls, que se compara con la tradición del derecho natural cristiano, articula, por el contrario, una particular concepción liberal de la justicia que define la legitimidad en términos enteramente políticos. Además, en su adhesión a la llamada 'exención de emergencia suprema' Rawls desecha un aspecto crucial del ius in bello, que prohíbe los ataques contra la población civil, como medio excepcional para la defensa y la promoción de un orden liberal internacional. Se argumenta que esta visión ideológica del orden postula una concepción excluyente de la justicia en un mundo cultural y políticamente diverso y, por lo tanto, alienta el conflicto, la resistencia y la lucha entre los Estados liberales y no liberales, e incluso fortalece la autocracia más allá de la zona liberal de la paz. Una visión más tolerante, expresada por Terry Nardin en su concepción de 'moral común', es parecida a la de Vitoria en el sentido de concebir el orden como algo emanado no de principios políticos, sino de principios justos, y expresa, mediante un lenguaje ético contemporáneo, los principios fundamentales de la tradición de la guerra justa establecidos por el propio Vitoria.

Palabras clave: Teoría normativa de las relaciones internacionales, John Rawls, Francisco de Vitoria, política internacional, derecho internacional.

This article explores two approaches to the issues of international legitimacy, order and the recourse to war. The first harks back to the beginnings of the modern statessystem and international politics. Francisco de Vitoria (1483-1546) and his neo-scholastic colleagues, the so-called theologian-jurists of the School of Salamanca, fashioned a kind of legal and philosophical thinking which outlined and described domestic and international politics within a traditional, indeed Thomistic, framework of justice. Their works on natural law are a point of departure for early modern political theory, constitute an integral part of the tradition of legal philosophy (iusnaturalism), and served to provide the development of international law with an initial ethical stance on its foundational principles and on the norms governing the conduct of war. ${ }^{1}$ For these thinkers, the legitimacy of a state and of international order was determined not by its political or, indeed, religious complexion, but by the extent to which it served the purposes of the common good conceived as the maintenance of justice. Equally, the just principles governing the conduct of war, according to the 'law of peoples' -or the ius gentium, were to be adhered to strictly since they were considered principles that preserved the idea of justice in practice. ${ }^{2}$ As a kind of justice-based view of international society, Vitoria's perception of order fosters a brand of universalism that is opposed to what Ken Booth has criticized as 'non-inclusive universalisms' or universalisms which "privilege power

1 On this, see Ernest Nys, ed. Francisci De Victoria: De Indis et de Iure Belli Relectiones, The Classics of International Law, vol. 7 (Washington: Carnegie Institution of Washington, 1917); J. B. Scott, The Spanish Origin of International Law: Francisco De Vitoria and His Law of Nations (1934); James Brown Scott, The Catholic Conception of International Law (Washington: 1934). A contemporary collection of his writings may be found in A. R. Pagden and Jeremy Lawrence, eds., Francisco De Vitoria. Political Writings, Cambridge Texts in the History of Political Thought (Cambridge: Cambridge University Press, 1991).

2 See Francisco de Vitoria, "On the Law of War (De Iure Belli)", in Political Writings, ed. A. R. Pagden and Jeremy Lawrence, Cambridge Texts in the History of Political Thought (Cambridge: Cambridge University Press, 1991). 
over people ${ }^{\prime \prime}$ because the exercise of power is seen as being restrained by universal standards of natural right.

Five centuries later, John Rawls provides an avowedly liberal conception of justice that appraises the legitimacy of non-liberal states in political terms and, exceptionally (and unaccompanied by a more thorough discussion) exempts itself from important requirements of the laws of war. Despite a self-styled appeal to issues such as human rights, justice, and reciprocity, inter alia, his undercutting of actual law or of its norms by political imperatives would seem to be a distinguishing characteristic of John Rawls's Law of Peoples in matters concerning the use of force between liberal zones of peace and other non-liberal peoples. The Rawlsian 'Law of Peoples' is, he maintains, "a political conception of right and justice that applies to the principles and norms of international law" ${ }^{4}$ However, I argue that the principles and norms that are undermined in his excursus are the laws of war and, in a broad sense, the principle of sovereign equality and self-determination. The first Rawls achieves by appealing to the 'supreme emergency exemption', which sanctions the use of force and undercuts the principles of the ius in bello. The second, he achieves by establishing liberalism as a universal paradigm for political order in international affairs. Because Rawls's treatise is too broad to examine as whole here, I merely wish to focus on three basic points: his conception of order and peace as a function of the expansion of liberal democratic principles throughout the international system, its position as a standard of legitimacy, and the appeal to exceptional methods of force in the achievement of a democratic peace.

To this effect, I suggest that if a premiere trait of the modern European states-system in its historical development has been toleration and not Holy Wars, as Vincent put it, ${ }^{5}$ then an integral feature of contemporary international affairs has been the primacy, in Western political culture, of a liberal democratic ethos that has undertaken a "civilising mission" which relegates unto itself a "greater entitlement to speak on behalf of the whole of international society". ${ }^{6}$ This is, as Clark put it, the ideological politics of exclusion but not of toleration. ${ }^{7}$ The point, however, is that Rawls's very brief discussion of the 'supreme emergency exemption" philosophically buttresses arguments that justify war by way of, for instance, what Goodman views as "security-based and strategic rationales" ${ }^{\prime}$ In addition, this line of reasoning thus reinforces arguments favoring the opting out from customary norms associated with the laws of war. ${ }^{9}$ Also, the position

3 Ken Booth, "Three Tyrannies", in Human Rights in Global Politics, ed. Tim Dunne and Nicholas J. Wheeler (Cambridge: Cambridge University Press, 2001; reprint, 1999), 61.

4 John Rawls, The Law of Peoples: With "the Idea of Public Reason Revisited" (Cambridge, Massachusetts: Harvard University Press, 1999; reprint, 2003), 3.

5 RJ Vincent, "The Factor of Culture in the Global International Order", Yearbook of World Affairs 34 (1980): 256.

6 Ian Clark, “Democracy in International Society: Promotion or Exclusion?”, Millennium: Journal of International Studies 37, No 3 (2009): 575.

$7 \quad$ Ibid., 581.

8 See Ryan Goodman, "Controlling the Recourse to War by Modifying Jus in Bello", 2009 Yearbook of International Humanitarian Law (2009).

9 See David J. Luban, “Opting out of the Law of War: Comments on 'Withdrawing from International Custom'”, Yale Law Journal 120 (2010). 
fostered by the Rawlsian vision of the 'law of peoples' conflates the idea of justice with a politically determined standard of judgment that recasts international legitimacy as a function not of domestic justice, but ultimately of regime form. This attempt to construct a 'law of peoples' on new grounds may be seen as a renovated American edition of the erstwhile European 'standard of civilization' wrought by empire. In any case, these two particular modes of thought may be fruitfully explored here for the following reasons:

a) Both views emerge from political circumstances that enjoined expansion and required compliance to the imperatives of either religious or political doctrine. While imperial Spain wrought dominance through methods that included the savage implementation of force based on religious judgment, the works of dissident neo-scholastics such as Francisco de Vitoria, while drawing upon the just war tradition, reformulated and articulated norms that sought the structuring of interstate relations within a framework of justice and just means in the use of force. This thinking, in fact, also contributed to the development of international law taken up later by thinkers such as Grotius, Gentili, Pufendorf and others. ${ }^{10}$ Rawls's position, by contrast, overtly undermines this established tradition by placing a greater premium on politics than law and by setting liberal democracy as a universal standard by which to judge non-liberal peoples.

b) The strategy of examining this disparity between one worldview and another opens an avenue of inquiry that allows us to examine the possible consequences arising from a wholly political approach to international affairs that, when necessary, disregards law itself. I argue that the Rawlsian approach, in its appeal to peace through exceptional means and circumstances (and as an ultimately non-inclusive theory of order), is actually more conducive to conflict. Vitoria's traditional approach, as well as Terry Nardin's 'common morality' position, is more tolerant and marked by much greater restraint in the implementation of force.

c) Finally, Rawls himself compares and contrasts his 'law of peoples' with the Christian natural law tradition in matters concerning the recourse to force. In doing so, he rejects important aspects of that tradition as it stands in current law.

To be clear, the argument I wish to develop does not espouse nor favor religious doctrine as a basis for a just world order. Rather, it rejects both religion and political ideology $y^{11}$ as a basis for inter-state relations. Similarly, neither is this a critique of the liberal philosophical tradition nor of liberal ideas. It stands as a critical assessment of

10 Malcolm N. Shaw, International Law, 5th ed. (Cambridge: Cambridge University Press, 2003), 22-31.

11 By ideology I am referring to any distinct belief system that seeks to shape society according to particular conceptions of political, economic, and social organization, as well as the values, political or otherwise, that underpin them. Various interest elites and purveyors of 'power', whether we speak of communism, socialism, liberalism or any other, articulate all such ideologies. Similarly, in the realm of the international, like-minded core states (such as the liberal democratic regimes of the United States and Europe), attempt to mold and shape the structure of the international system through diplomacy, economy, soft power, or military force. (For a broad overview of the subject, see the unpublished paper, L. Valenzuela-Vermehren", Ideology and Political Order: A Short Intellectual History with Implications for the International". 2011.) It is equally the case that ideologies, as one scholar notes, shape policymakers' perceptions of threats to security interests. See Mark L. Hass The Ideological Origins of Great Power Politics 1789-1989 Cornell Studies in Security Affairs, Edited by Robert J. Art, Robert Jervis and Stephen M. Walt. Ithaca: Cornell University Press, 2005. 
a particular expression of liberalism outlined in the Law of Peoples, which has chosen to set itself as both a standard by which to judge other societies, and as a philosophical proposition directed at shaping the world in its image. Hence, the assessment set forth here appraises the question of means, which is at odds with the ethics of war, as well as the viability and desirability of molding international order according to particular and specific political principles. My argument, therefore, does not disparage the inherent values or the ultimate ends sought in the Rawlsian position, which, in any case, may uncontroversially be deemed as unrealistic or impractical in a culturally diverse world. This is thus much less against liberal democracy than it is against those arguments which, speaking on its behalf, suggest that it may be grafted upon the world through methods that sanction the illegal implementation of force.

After a brief examination of the concept of legitimacy, the first section will compare both approaches as a way of understanding the fundamental qualitative differences between them. The second section explores the Rawlsian and Vitorian attitudes toward the methods employed in the conduct of war. The third section will examine Terry Nardin's more modest conceptualization of justice as it relates to the use of coercion in international relations. Nardin's position is similar to the Vitorian attitude toward relations between states and is a more practical contemporary statement about the relationship between order and justice in the realm of the international.

\section{THE POLITICS OF LEGITIMACY}

Standard views of legitimacy and recognition tend to define it in terms of 'collective' views of it. Wight defined legitimacy as "the collective judgment of international society about the rightful membership of the family of nations". ${ }^{12}$ That is, legitimacy in international society has increasingly been determined by a politically based and ideological consensus among dominant states. Hence, Kissinger noted, "an order whose structure is accepted by all major powers is 'legitimate'". ${ }^{13}$ Similarly, Clark himself notes that legitimacy is no longer about the justice of a particular order "but only about the degree of consensus with which it is regarded by principal states". ${ }^{14}$ According to Bukovanski, legitimacy is not related to "some abstract conception of right but, rather, to the norms of a specific culture system at a given time ${ }^{\prime 15}$ that are associated with cultural belief systems of those actors constituting the prevailing "system of rule". ${ }^{16}$ This has meant the emergence of

Likewise, this has a direct bearing on the intellectual and philosophical ruminations characteristic of democratic peace thesis discourse and the Rawlsian perception of the world beyond the liberal zone since many nonliberal societies are, in practice and in theory, seen as potential threats to Western security.

12 Martin Wight, "International Legitimacy", in Systems of States, ed. Hedley Bull (Leicester: Leicester U.P. in association with the London School of Economics and Political Science, 1977), 153.

13 Henry A. Kissinger, A World Restored: The Politics of Conservatism in a Revolutionary Era (London: Victor Gallancz, 1977), 145.

14 Ian Clark, “Legitimacy in a Global Order”, Review of International Studies 29 (2003): 84.

15 Mlada Bukovansky, Legitimacy and Power Politics: The American and French Revolutions in International Political Culture (Princeton: Princeton University Press, 2009), 24.

16 Clark, "Legitimacy in a Global Order", 80-81. 
efforts to promote democracy that have included attempts at its institutionalization internationally as well as its promotion through the use of force. Indeed, if we look back to the interwar period, while the League Covenant did not make any specific reference to democracy, initially Woodrow Wilson did suggest that democracy become the criteria for the creation of a League of Democracies. The problem remained, however, that the non-inclusive nature of the League, was bound to failure by setting it apart from other states. This simply served to create a new balance of power that eventually gave rise to the conflicts of the Second World War. ${ }^{17}$ By the end of the Cold War era, the democratic principle became part and parcel of treaties including the Vienna Declaration (1993), the Charter of Paris (1990), and the Inter-American Charter (2001). More recently, political advisors to the 2008 US presidential candidates had suggested the creation of a Concert of Democracies aimed at strengthening security cooperation among liberal democratic states. The interesting upshot of the initiative was to have the Concert act as "an alternative source of authority for collective action on interventionist questions likely to divide the UN Security Council". ${ }^{18}$ This included the implementation of force. We may hence see that legitimacy is closely linked to considerations of power politics and reflects the qualitative differences, in terms of general capabilities, between dominant states and the rest of the members of the international system. Ikenberry has warned against this kind of power political policy stance in which order becomes the function of the dominant view of order itself thus creating conditions conducive to instability. ${ }^{19}$ Legitimacy and legitimate orders, I argue, should be seen as a function of just relations and of the preservation of the attitudes enshrined in the 1970 Declaration of the Principles of Law. These include not only the ideas of independence, sovereignty and non-intervention (established as constitutive of the fundamental rights of states) but also the corollary assertion that "each state has the right freely to choose and develop its political, social, economic and cultural systems". Likewise, "each state has the duty to respect the personality of other states" ${ }^{20}$ Within the academic milieu, the political activities, initiatives and attitudes indicated above find their philosophic utterance as well. American political power and American political philosophy have thus trodden upon the parallel roads of practice and theory with a view to securing political and intellectual supremacy in the preservation or expansion of emplacements of democratic peace. But how do Rawls's efforts particularly seek to accomplish this and what may be suggested as a sounder alternative?

\section{RAWLS AND THE LIBERAL 'WELTANSCHAUUNG’ IN ‘THE LAW OF PEOPLES’}

Here I wish to discuss the Rawlsian 'ideal utopia' not in terms of the theoretical virtues of his excursus but of the viability of his thesis as a philosophical source of policy-

\footnotetext{
Clark, "Democracy in International Society", 564-565.

For a more complete discussion of this point, see ibid., 573-577.

See G. John Ikenberry, After Victory: Institutions, Strategic Restraint, and the Rebuilding of Order after Major Wars (Princeton: Princeton University Press, 2000).

Shaw, 193
}

20 
making generally speaking. The liberal worldview is generally popular, of course, as some have argued, because it has historically espoused self-determination, played a role in decolonization and has, as a system of ideas centering on liberty, promoted an evergrowing human rights culture. In a phrase, democracy has become, as Mayall put it, an "ingredient of modernity". ${ }^{21}$ However, the progression of historical events points to a transition from a Cold War policy of containment to one of actively encouraging the enlargement of democratic space, ${ }^{22}$ a manner of liberal lebensraum with philosophical pillars shooting up from the liberal ivory tower. The triumphalist literature of Fukuyama's End of History and Rawls's conception of world order are prime examples of an attempt to both extol the virtues of liberal thought and society as well as a wholehearted effort to transform the liberal cultural milieu into a universal standard of politics.

Rawls's account of justice in the international system draws upon his well-known definition of "justice as fairness" as discussed in his Theory of Justice (1971). As a kind of continuation of traditional social contract theories, the concept of justice developed by Rawls involves the evocation of a hypothetical state of nature in which 'rational' and 'reasonable' individuals are able to agree on the basic principles of justice (rights and duties) governing civil society. This agreement or social contract, made possible through the artifice of the "veil of ignorance", represents what he referred to as the original position. Representatives of civil society attempt to achieve a type of justice whereby fundamental social goods (liberty, wealth, reciprocity, etc.) are available equally to all unless an unequal allotment of such goods proves more advantageous for the least favored of civil society. The Law of Peoples attempts to incorporate this conception of justice to the realm of international relations.

Rawls's work is essentially an extension of his social contract theory, discussed in his Theory of Justice, to the international order. The concept itself he takes only nominally from the Roman ius gentium. But the meaning accorded to it differs in that it now points to those "particular principles for regulating the mutual political relations between peoples $[\ldots] "{ }^{23}$ To this extent, it is, as Brown notes, an account of "relations between liberal and non-liberal peoples [...]". ${ }^{24}$ Rawls thus establishes a particular political doctrine, liberalism, as a framework through which relations between peoples may be rightfully shaped, judged, and courses of action, such as intervention, implemented. To this effect, Rawls's image of the world is marked by the presence of "reasonable liberal peoples", "decent peoples", "outlaw states", "societies burdened by unfavorable conditions" and, finally, "benevolent absolutisms". ${ }^{25}$ As Beitz's review of The Law of Peoples suggests, a central question in such a world is that of determining what political institutions would have to be like in order to foster cooperation between peoples. The prospects for peace in international relations would depend upon locating a basis upon which cooperation

\footnotetext{
21 James Mayall, “Democracy and International Society”, International Affairs 76, No 1 (2000): 65. Ibid., 61.

John Rawls, The Law of Peoples (Cambridge, Mass.: Harvard University Press, 1999), 3.

Chris Brown, Sovereignty, Rights and Justice: International Political Theory Today (Cambridge: Polity Press, 2002), 174.

25 Rawls, The Law of Peoples, 4.
} 
is possible. ${ }^{26}$ The "second original position" takes us to the sphere of the international political order wherein, by some means, representatives of peoples can hypothetically arrive at certain shared principles capable of ordering relations between states. Rawls's image of international relations consists, furthermore, of making an essential distinction between liberal and decent peoples (who would seem to coincide on the eight principles outlined in the text), and other societies that do not ostensibly adhere to them. This distinction forms the basis, or the raison d'être, of foreign policy objectives. It becomes increasingly apparent, however, that he draws upon a strong cultural framework (his own) consciously aimed at determining standards of state legitimacy within the realm of international politics. In his own words: "it is important to see that the Law of Peoples is developed within political liberalism and is an extension of a liberal conception of justice for a domestic regime to a Society of Peoples" ${ }^{27}$ Liberal and decent peoples, unlike others, form that exclusive Society of Peoples in which other states do not find representation. In this sense, Beitz is correct in assessing the law of peoples as not universal, ${ }^{28}$ for it cannot by doctrine accept as members in good standing states that have "outlaw" status, or overly burdened states whose cultural traits have impeded their accession to the sphere of the enlightened liberal community.

It is worth noting the Rawlsian distinction between 'reasonable liberal peoples' as what he designates as 'decent peoples'. Such peoples' "basic institutions meet certain specified conditions of political right and justice and lead its people to honor a reasonable and just law for the Society of Peoples".$^{29}$ These are nonliberal societies that are recognized as "equal participatory members in good standing of the Society of Peoples [...]". ${ }^{30}$ Decent societies may be institutionally diverse, and may be religious or secular. Such societies, Rawls argues, are not aggressive and must achieve foreign policy objectives "through diplomacy and trade and other ways of peace". They also secure human rights norms, uphold the principles of justice, the rule of law and possess a 'decent consultation hierarchy' as well as a "capacity for moral learning", among other traits. ${ }^{31}$ Such societies are tolerated and remain in good standing by virtue of traits that make them similar to liberal peoples. Rawls thus recognizes a segment of the international order that, while not wholly liberal, nevertheless is subject to 'toleration' understood as a policy of not "exercising political sanctions -military, economic, or diplomatic- to make a people change their ways". ${ }^{32}$ To this extent, there exist, in principle, states that partake of the

Charles R. Beitz, “Rawls's Law of Peoples”, Ethics 110, N 4 (2000): 672. Rawls sets forth the following principles as the principles of justice "among free and democratic peoples: 1 . Peoples are free and independent, and their freedom and independence are to be respected by others; 2 . Peoples are to observe treaties and undertakings; 3. Peoples are equal and are parties to the agreements that bind them; 4 . Peoples are to observe a duty of non-intervention; 5 . Peoples have the right to self-defence but no right to instigate war for reasons other than self-defence; 6 . Peoples are to honour human rights; 7. Peoples are to observe certain specified restrictions in the conduct of war; 8. Peoples have a duty to assist other peoples living in conditions that prevent their having a just or decent political and social regime". Rawls, The Law of Peoples, 37. Rawls, The Law of Peoples, 9.

Beitz, 676.

Rawls, The Law of Peoples, 60.

Ibid., 59.

Ibid., 64-7.

Ibid., 59. 
liberal peace and yet it is curious to see that even like-minded societies are subject to scrutiny and are the object of such benevolent toleration. Rawls does not draw upon historical examples of decent peoples but does conjure up a Muslim paradigm in his imaginary "Kazanistan".

Beitz's claim that the law of peoples is not universal, however, does not preclude the possibility of universality, which it ideally seeks. Rawls does underscore the idea that he is attempting to outline the principles of a foreign policy of a just liberal people, which recognizes that there exist nonliberal points of view. But, "How far nonliberal peoples are to be tolerated", he writes revealingly, "is an essential question of liberal foreign policy". ${ }^{33}$ Hence, "the guiding principle of liberal foreign policy is gradually to shape all not yet liberal societies in a liberal direction, until eventually (in the ideal case) all societies are liberal". ${ }^{34}$

These standards, however, far surpass the criteria of legitimacy proffered by Vitoria because they include not only criteria with which he would agree (e.g. respect for fundamental human rights), ${ }^{35}$ but also particular and specific social and political arrangements (as well as "rational" and "reasonable" liberal attitudes) that implicitly characterize the "worthiness" of certain societies over others. The liberal foreign policy of this new law of peoples, moreover, would seem to appeal to what Martin Wight deemed as the drive toward the achievement of doctrinal uniformity within the states-system. ${ }^{36}$ It recognizes such doctrinal diversity as exists not as an occasion for its preservation but as something, for the time being, to be "tolerated" and as an opportunity for eventually constructing the world in its own image.

The political objectives inherent in Rawls's law of peoples are bolstered by his considerations on the nature of stability between states, which is linked to his appeal to Michael Doyle's controversial view of the democratic peace. "The absence of war between major established democracies", he writes, "is as close as anything we know to a simple empirical regularity in relations among societies". ${ }^{37}$ But this is not the case all the time, he admits, since the democratic peace does sometimes fail. Drawing upon the examples of covert intervention in Guatemala, Chile and Iran, Rawls argues, it should come to us as no surprise that democratic regimes "often intervene in weaker countries, including those exhibiting some aspects of a democracy, or even that they should engage

33 Rawls, The Law of Peoples, 10.

34 Ibid., 59-60.

35 Anderson notes how Rawls argued his conviction that his principles of justice are quite compatible with diverse religious doctrines: "To show that such a consensus would comprise his principles of justice, Rawls was now obliged to argue that all major religions contained moral codes compatible with them. In The Law of Peoples, the two lines of argument merge. Universal human rights are deducible from the choice that variant peoples, endowed as they are with differing faiths, would make if assembled together in an original position. Since they form a narrower set than the full range of liberal rights, decent as well as democratic societies will select them; symptomatically, Rawls's examples of the former are consistently Muslim". Perry Anderson, “Arms and Rights", New Left Review 31 (2005): 16-17.

36 Gabriele Wight and Brian Porter, eds., International Theory: The Three Traditions (New York: Holmes \& Meier, 1991), 41.

37 Rawls, The Law of Peoples, 52-53. 
in war for expansionist reasons". ${ }^{38}$ But more surprising is his contradictory assertion a few lines further on: "Though democratic peoples are not expansionist, they do defend their security interest, and a democratic government can easily invoke this interest to support covert interventions [...]". ${ }^{39}$ It is true that Rawls sees such interventions as occurring without the knowledge of public opinion (and one assumes he says this disapprovingly), and that his model of justice is but a "realistic utopia" which he holds, at any rate, to be achievable.

The argument nonetheless does not resolve the obvious question about why the world should have to settle for the apparent comfort furnished by the "statistics" of liberal democratic politics and associated peace. Nor does it resolve the issue of the methods of foreign policy, which may be considered both immoral as well as illegal. There is, in this respect, another view on the conduct of liberal societies. Franz Neumann's disquisitions on the politics of the liberal state in history offers a significantly different account of the question of its conduct in domestic and international politics.

The liberal state has always been as strong as the political and social situation and the interests of society demanded. It has conducted warfare and crushed strikes; with the help of strong navies it has protected its investments, with the help of strong armies it has defended and extended its boundaries, with the help of the police it has restored "peace and order". It has been a strong state precisely in those spheres in which it had to be strong and in which it wanted to be strong. This state, in which laws but not men were to rule (the Anglo-American formula)-i.e., the Rechtstaat (the German formula)-has rested upon force and law, upon sovereignty and freedom. Society required sovereignty to destroy local and particularist forces, to push the church out of temporal affairs, to establish a unified administration and judiciary, to protect boundaries and to conduct war, and to finance the execution of all these tasks. Political liberty has been necessary to modern society for the safeguarding of its economic freedom. Both elements are indispensable. There is no modern theory of law and state, which does not accept both force and law even if the emphasis accorded to each of these components, has varied in accordance with the historical situation. ${ }^{40}$

This alternate view suggests that perhaps the democratic peace hypothesis, in the sphere of inter-state politics, is not necessarily the most compelling question at stake. More decisive than this is precisely the question of the means by which that peace is to be achieved when the emphasis is placed on the use of force. Neumann stresses the view that liberal societies do use force when necessary (as Rawls has also correctly observed) and that, consequently, any appeal to the idea of the democratic peace must be able to justify the implementation of force for reasons other than a self-congratulatory view of itself.

Franz Neumann, "The Change in the Function of Law in Modern Society", in The Democratic and the Authoritarian State: Essays in Political and Legal Theory, ed. Herbert Marcuse(Glencoe, Illinois: The Free Press, 1957), 22-23. 
Vitoria, in this respect, recognized the importance of proceeding upon a different basis in inter-state affairs: the principles of justice and equality, which should govern relations between states, irrespective of political and religious complexion. As in the case of the religious justifications for expansion that Vitoria repudiated, the democratic peace argument does not, in and of itself, create a rational and just universal standard of judgment, or a basis upon which to govern inter-state affairs in a politically and culturally diverse international community. For Vitoria, the universal standard, by contrast, was the very essence and dignity of man, but not the political and social values and customs of this or that particular community to which man belongs. Quite controversially, Vitoria argued in the sixteenth century that neither Emperor nor Pope were true masters of the globe. ${ }^{41}$ Nor was it the case that religious difference could form the basis of Spanish domination for the indigenous communities already possessed dominion before the arrival of the Spaniards. ${ }^{42}$ Neither was it the case that they could be forced to accept the Christian faith for "these are things for which they cannot be furnished with evident proof by natural reasonings". ${ }^{4}$ In this view, neither difference of political or social doctrine, no less than difference of religion, can justify war or the expansion of political "zones" of a Kantian-inspired perpetual peace.

The Rawlsian position, nonetheless, is easily transformed into the democratic peace doctrine set forth by Doyle, and to which Rawls admittedly adheres. This includes either a balance of power policy toward non-liberal states as a means of defense, or a more aggressive policy of expansion by methods, which may include force. ${ }^{44}$

Whatever form such prescriptions take, they are, in a sense, a contemporary expression of the principle of popular legitimacy in international affairs borne of the French revolutionary experience in its essential disdain for dynastic systems of governance. Wight thus noted the increasingly ideological character of popular legitimacy since the era of the World Wars. ${ }^{45}$ In a statement reminiscent of Rawls's comments on covert operations, Wight found

41 Pagden and Lawrence, eds., 253, 260.

42 Ibid., 251

$43 \quad$ Ibid., 263.

44 Doyle refers to measures such as "inspiration", "instigation", and "intervention". Tim Dunne, "Liberalism", in The Globalization of World Politics: An Introduction to International Relations, ed. John Baylis and Steve Smith(Oxford, New York: Oxford University Press, 2005), 172.

45 The question of legitimacy became of central concern to American international lawyers. In international law the issue of legitimacy is posed as the legal principle of recognition of states. The intertwining of political and legal imperatives during the inter-war period turned the question of recognition into the object of much academic analysis. "Perhaps the most important question of foreign policy confronting the incoming administration", wrote Amos S. Hershey in 1921, "will be that of entering upon trade (and possibly diplomatic) relations with Soviet Russia", Amos S. Hershey, "Recognition of New Governments", American Journal of International Law $15, N^{\circ} 1$ (1921): 59. Hershey's general argument centred upon the legal precedents (many from the nineteenth century) favouring the recognition of the Bolshevik government by the United States. In such legal expositions the tendency seemed to have been one that favoured recognition on the basis of Russia's fulfilling the de jure requirements as a constituted government. A similar conclusion had been advanced in 1932 by P.M. Brown who argued that the granting or withholding of recognition should not become a function of political considerations, Philip Marshall Brown, “The Recognition of New Governments", American Journal of International Law 26, No 2 (1932): 338. It is interesting to note, parenthetically, that Czarist Russia did not recognise the new American Republic of 1776 until 1809, as it did not look upon such popular government with favorable eyes. A discussion of this issue may be found in Chandler P. Anderson, "Recognition of Russia", American Journal of International 
in this new doctrine a curious but thought-provoking paradox: "the more passionately it has been asserted, the less it has led to impartial popular consultation". ${ }^{46}$ In any case, it is interesting to follow Wight a bit further on this matter. The principle, he demonstrates, acquired particularly forceful proportions on the occasion of the Versailles treaty.

In October 1918 President Wilson had proclaimed as a condition of making peace the destruction of arbitrary rule in Germany, by which he meant the imperial and Prussian constitutions. No, to be legitimized, Germany needed more than this degree of self-determination. She needed to be purged of those Germans who had violated the principles of civilized society. She was occupied by the Allies with the purposes, among others, of destroying the Nazi Party, eradicating Nazi institutions, and reeducating the German people in the principles of democracy. ${ }^{47}$

Obviously, Wight is placing emphasis (our dismissal of National Socialism notwithstanding) on a fundamental shifting of attitudes in international society regarding the proper standing of its members and the requirements for that rightful membership. An unsurprising keynote feature of that shift is that legitimacy is often determined by the dominant powers of international society on the basis of a political standard; and it is worthy of note that such a position of dominance (and concomitant ideological selfconfidence) precludes, in practice, the possibility of judgment in terms of whether or not dominant powers may, in turn, be considered by weaker states as "rightful members" of international society on similar, but also specifically ideological grounds.

I am referring to the logic contained in the colloquialism "might makes right;" that the standards of legitimacy of international society increasingly depend, in this respect, not on universal principles of justice, such as those embodied in Vitoria's ius gentium, but on political principles supported by the overwhelming character of force. The responses on the part of relatively powerless states have often drawn upon principles of international law in objecting to such judgment and accompanying interventions. This had certainly been the objection that often obtained in North-South relations throughout the period of American predominance in Latin America during the Cold War era. The charge of "imperialism" which echoed through many of these states certainly pointed to the belief that Great Power interference in their internal political affairs on ideological grounds constituted illegitimate action against the notion of sovereign independence and self-determination, which the Great Powers, including the Soviet system, claimed for themselves but not for others. As Rawls himself put it, liberal peoples do seek to secure their strategic interests even if this means undermining law. Interventions and their associated human costs in Latin America proved, in this respect, to be striking examples of the politics of forcible compliance, of strategic interest diplomacy based on the notion of a "virtuous" extension of particular articles of faith into nonliberal

Law 28, $\mathrm{N}^{\mathrm{o}} 1$ (1934).An enthralling historical account of Russian-American diplomatic relations may be found in Malbone W. Graham, "Russian-American Relations, 1917-1933: An Interpretation”, The American Political Science Review 28, No 3 (1934): 387-409.

46 Wight, "International Legitimacy", 165

$47 \quad$ Ibid., 166. 
communities. Such policy precedents and prescriptions allow us to claim that there is no rational reason why the world should not have been Soviet or Chinese or Muslim (in theory) rather than liberal, given the power to achieve such dominance. In any of these hypothetical cases legitimacy would have been a question not of just principles, as Vitoria understood them, but of a "justice" understood in purely ideological terms.

In De iure belli, Vitoria condemned the motivations of empire and expansion by stating Non est iusta causa belli amplificatio imperii (enlargement of empire cannot be a cause of just war), which was preceded by the assertion causa iusti belli non est diversitas religionis (difference of religion cannot be a cause of just war). ${ }^{48}$

The link between ideology and power becomes more obvious in this light. The expansion of a doctrine will hence become a function of power or, as in Waltz's Realism, 'capabilities' within the structure of the international system. Power, in this view, attempts to transform a given order into one that "commands the allegiance of other states within the order" ${ }^{49}$ Likewise, the shared political agenda of like-minded and strong "core" states, in this view, thus determines the nature and requirements of legitimacy, which they then either bestow upon or withdraw from states throughout international society. ${ }^{50}$ Wight discussed this point in similar terms.

[In such a world] the principles of transformation [of the states-system] will establish themselves first, in accordance with the law of uneven development, in a single country, whether an insignificant city-state like seventeenth century Geneva or in a Great Power like eighteenth century France or twentieth century Russia. This state becomes the bearer and exemplar of the new order, and its relations with the unregenerate society of states will reproduce the relations of the Church militant with the secular and infidel world. There follows no single or simple notion of international law. One set of beliefs is governed by the idea that the whole is prior to the part, that the greater includes the less, and the state is or ought to be subordinate to the international community. ${ }^{51}$

The idea of "reasonable liberal peoples" forging a community of "decent" peoples (and eventually of creating a world in its own image) based on a culturally specific political doctrine is similar to the medieval view of relations with the "infidels" which Vitoria so vigorously repudiated. He saw in the forceful extension of Christianity methods that led to the devastation of innocent peoples. A chief achievement of Vitoria's thought was to separate the spiritual order of man (the order of religious doctrine and belief which depended on individual choice) from the natural order (the order of universal principles -as in the principles of justice- applicable to all individuals). Belief in Christianity, Vitoria

48 Pagden and Lawrence, eds., 302-303.

49 Ikenberry, 4.

50 One recalls here the arrival of the Spanish conquerors who read aloud the Requerimiento outlining the virtues of Christianity and Spanish rule while threatening the indigenous populations (illegitimate in their view) with violence if they did not comply with its precepts.

51 Martin Wight, "Western Values in International Relations", in Diplomatic Investigations: Essays in the Theory of International Politics, ed. Herbert Butterfield and Martin Wight(London: George Allen and Unwin, 1966), 94. Revealingly, modern international law still refers to the conduct of war in the terminology of the Catholic just war tradition (ius in bello). 
suggested, could only arise from a personal and sincere conviction of the peoples recently discovered. Even if the faith had been announced "probably and sufficiently" this still remained an inadequate reason for engaging in war and usurping their property; as Aristotle had shown, "belief is a matter of the will, but fear considerably diminishes the freedom of the will" . ${ }^{52}$ Vitoria was attempting to demonstrate that methods of violence and intimidation were not proper means for achieving conversion to the faith; that those who did so were acting out of self-interest, but not in the interest of God. Conversion is therefore tainted when articulated in conditions that thwart free will. "Hence", Vitoria held, "the barbarians cannot be moved by war to believe and accept the Christian faith, but only to pretend to believe that they accept the Christian faith, and this is monstrous and sacrilegious". ${ }^{53}$ It would seem that this critical line of reasoning is equally applicable to secular political ideals.

Generally considered, Rawls's law of peoples intertwines the attitudes of liberal doctrine (particularly in the idea that diverse peoples can rationally agree upon norms of international comportment) with specifically political aims. However, a policy framework whose ultimate ambition is the absorption of communities into its standards of political legitimacy destroys the intermediate conception of international society, fashioned by Vitoria and others, which argues for much greater restraint in the conduct of its members and the primacy of formal equal status between states. Intervention may become a mechanism not for the defense of the fundamental rights of individuals or state rights but for the maintenance of a particular political order, which may indeed include such rights, but which also seeks to enter into the sphere of personal choices and to thus shape the political alternatives of particular communities. It is what Nardin has called "impermissible coercion" as we shall see below. In this light, Rawls's general view of his law of peoples is more of a "Revolutionist" conception of international order based on a particularly Western political philosophy. ${ }^{54}$

\section{THE RAWLSIAN LAW OF PEOPLES AND CHRISTIAN NATURAL LAW: THE 'JUST' WAR IN LIBERAL PARLANCE}

Rawls compares and contrasts the law of peoples and Christian natural law. They are similar, he argues, in that both accept the possibility that peace among nations may be obtained. The essential difference lies in the way each doctrine is conceived. The natural

Ibid.

54 This assertion is, of course, not novel. Bleiker has noted Suganami's view of the English School's "Westcentricity"; its "insensitivity towards the undersides of the Europeanization of the world, the relative lack of engagement with non-Western cultures, or the strong confidence in the values of Western civilization and the resulting fear that other cultures could undermine these values". Similarly, he also points to O'Hagan's view that "English School scholars tend to privilege the Western experience and its values by using them as a measuring device to judge other societies". Roland Bleiker, "Order and Disorder in World Politics", in International Society and Its Critics, ed. Alex J. Bellamy(Oxford: Oxford University Press, 2004), 187. See also, Jacinta O'Hagan, Conceptualizing the West in International Relations (Houndmills: Palgrave Macmillan, 2002), 115; Hidemi Suganami, "Beyond the English School”, in Annual Convention of the International Studies Association (University of Birmingham: 2003), 12. 
law, Rawls stresses, "is thought to be part of the law of God that can be known through the natural powers of reason by our study of the structure of the world". 55 The law of peoples, however, while theoretically compatible with natural law, is nonetheless a set of principles expressed "solely in terms of a political conception and its political values". ${ }^{56}$ A more detailed comparison between the two systems is not forthcoming in his analysis since Rawls's discussion is concerned with focusing on what he labels the "supreme emergency exemption" in the conduct of war. Rawls establishes that both systems assert that wars are to be conducted in self-defense, and that, in principle; civilians cannot be direct targets in armed conflict. However, he espouses a crucial caveat to this principle.

Yet they [the Christian just war doctrine and the law of peoples] differ in that the principles for the conduct of war in the social contract conception include the supreme emergency exemption [...] Political liberalism allows the supreme emergency exemption; the Catholic doctrine rejects it, saying that we must have faith and adhere to God's command. This is intelligible doctrine but is contrary to the duties of the statesman in political liberalism. ${ }^{57}$

This exemption allows the liberal statesman to "set aside" in "certain special circumstances" the status of civilians as targets conventionally protected by the Christian just war doctrine $\mathrm{e}^{58}$ and, one should observe, contemporary international humanitarian law. Rawls has, as he admits, coined the term "supreme emergency exemption" by re-adapting the notion of "supreme emergency" discussed in Walzer's Just and Unjust Wars. Indeed, even the historical examples used by Rawls to justify this exemption are precisely the ones used by Walzer but which, unlike Walzer, he refers to approvingly. Thus the appeal to the essentially malevolent nature of the Nazi regime coupled with the military inferiority of the British forces at that time left Britain with "no other means to break Germany's superior power". Therefore, the "bombing of German cities was arguably justifiable". ${ }^{59}$

Walzer's account is somewhat more somber. The bombings of Dresden and other German cities had caused some 300,000 deaths and 780,000 wounded. Walzer notes how these figures had been the result of conscious decisions made in 1942 by Lord Cherwell and Churchill who supported a policy of indiscriminate bombing (commonly condemned, Walzer adds) aimed explicitly at destroying German working-class residential areas for the ultimate aim of lowering civilian morale. ${ }^{60}$ The framework for justification involved the application of a wholly utilitarian calculus. The well-intended aims of these military procedures (the defeat of German fascism) had somehow destroyed the rights of civilians (or their natural rights, Vitoria might have argued). But they were justified by concluding that such measures would bring victory sooner and thus ultimately save more lives than those sacrificed. Walzer's remarks are worth remembering here.

Rawls, The Law of Peoples, 104.

Ibid.

Ibid., 104-105.

A thorough outline of these prohibitions may be found in Shaw, chapter 21.

Rawls, The Law of Peoples, 98.

Michael Walzer, Just and Unjust Wars, 3rd ed. (NewYork: Basic Books, 1977), 256. According to Walzer, it seems the German bombing of Coventry, which served to justify British indiscriminate bombing, had been deliberately provoked by Churchill's earlier attack on Berlin. 
[...] such calculations need not be concerned only with the preservation of life. There is much else we might plausibly want to preserve: the quality of our lives, for example, our civilization and morality, our collective abhorrence of murder, even when it seems, as it always does, to serve some purpose. Then the deliberate slaughter of innocent men and women cannot be justified simply because it saves the lives of other men and women. I suppose it is possible to imagine situations where the last assertion might prove problematic from a utilitarian perspective, where the number of people involved is small, the proportions are right, the events hidden from the public eye, and so on. Philosophers delight in inventing such cases in order to test our moral doctrines [...] utilitarianism as it is commonly understood [...] encourages the bizarre accounting that makes them (morally) possible. We can recognize their horror only when we have acknowledged the personality and value of the men and women we destroy in committing them. It is the acknowledgement of rights that puts a stop to such calculations and forces us to realize that the destruction of the innocent, whatever its purposes, is a kind of blasphemy against our deepest moral commitments. (This is true even in a supreme emergency, when we cannot do anything else). ${ }^{61}$

Vitoria had been similarly clear on this issue in De iure belli (1539). He argued that it is never lawful to inflict death upon the innocent since it directly contradicts the rule, which establishes that a just war may only be waged when an injury has been previously received. ${ }^{62}$ War cannot be waged against those who have done us no harm. He further argues that in the same way within the commonwealth it is unlawful to kill the innocent for the evils committed by others, it is equally unlawful to "kill innocent members of [an] enemy population for the injury done by the wicked among them" ${ }^{\prime 63}$ If such measures were licit, a contradictory situation would arise wherein the war would be just on both sides, for the innocent would then have a right to defend themselves. But then Vitoria imagines a difficult situation similar to Walzer's and Rawls's Second World War examples. Would it be licit to attack a garrison or town knowing that innocent people are present in them? This is only "occasionally" permissible, he argues, and when the military objective in question is of the utmost importance and contributes to the victory of a just war. This may seem to be the same argument employed by Rawls, but it is at variance with it because of one crucial qualification. The example offered by Vitoria describes a situation in which "if a town is unjustly attacked and justly defended, it is permissible to fire artillery and other projectiles at the besieging enemy encampments, though there may be children or non-combatants among them". ${ }^{64}$ Vitoria justifies an attack upon a garrison or town only after a city has been subjected to an unjust military offensive. It is also an argument that, unlike Rawls's "supreme emergency exemption", does not justify the use of force against defenseless populations where enemy combatants are not present. But even in such cases where there is military presence, care must be taken to not cause greater evils by virtue of such action even if through such acts certain

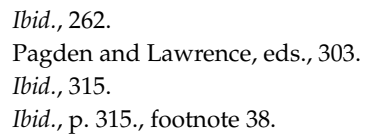


benefits are reaped. To the contrary, "it does not seem to me permissible to kill a large number of innocent people by indiscriminate bombardment in order to defeat a small number of enemy combatants". 65

In all fairness, Rawls does not routinely justify attacks against defenseless civilian populations, but the "supreme emergency exemption", which is conceptually underdeveloped in the text, opens a permanent backdoor on the traditional principles of the ius in bello and of contemporary international law. Except for the statement that the liberal statesman is bound to defending liberal democratic regimes by means of a just war, there is no further course of analysis; and the employment of the term "just war" acquires new meaning. That which was ordinarily impermissible in the conduct of war is now, under a liberal law of peoples, permissible. Yet we shall still call it a "just war".

The assertion that, in any case, "the statesman must look to the political world, and must, in extreme cases, be able to distinguish between the interests of the well-ordered regime he or she serves and the dictates of the religious, philosophical, or moral doctrine that he or she personally lives by" ${ }^{\prime \prime}{ }^{66}$ is a curious restatement of the classical Realist thesis of the foolishness of acting morally in an immoral world of anarchy. Rawls's liberal perspective sees itself encircled and threatened by states that are not "well-ordered" or "decent", and this requires locating windows of opportunity for securing, or expanding, the liberal zone of peace. Thus the law of peoples, while imbued with a particular sense of morality, has even by its own standards, recourse to immoral means occasioned by 'exceptional' circumstances.

Ultimately, Rawls issues liberal regimes a special mandate for their self-defense, for the determination of the legitimacy of other states, and for the resulting propagation of liberalism as a form of political organization. This position would seem to imply that liberal societies, in some manner or other, possess a particular virtue not yet understood by the non-liberal world at large. This attitude, of course, is far from novel. Kagan's overview of early American exceptionalism and foreign policy tells us much about the historical roots of American thinking vis a vis the position of non-Western communities. The unrestricted colonization and expansion of settler communities in the colonies represented the inevitable "unfolding of an Anglo-Saxon destiny". ${ }^{67}$ The achievement of "civilization, religion, and [even] security were justifications for and by products of conquest and expansion in the seventeenth and eighteenth centuries", and in a sense, Kagan argues, offered an unparalleled opportunity for articulating "Lockean theory and practice" ${ }^{68}$ This was buttressed by the argument that empire and liberty were not antithetical. Indeed, liberty and American expansion "need not be incompatible with the preservation and extension of republican freedom at home and abroad". ${ }^{69}$

67 Robert Kagan, Dangerous Nation: American Foreign Policy from Its Earliest Days to the Dawn of the Twentieth Century (New York: Vintage Books, 2007), 12. 
This early variant of the democratic peace thesis, already nurtured by self-confidence, required compliance for the creation of an imagined new world. What had to be done, according to the records of the Virginia Company stockholders in London, was to "bring the infidels and savages lying in those partes to human civitie and to a settled and quiet governmente" ${ }^{\prime 7}$ and this would be accomplished by force and education. These, of course, were not legal arguments but political ones based on ideology and even religious doctrine.

Neither international law, nor Vitoria's conception of the law of nations, proceed upon such a basis. ${ }^{71}$ The admissibility of war or imperial expansion will depend not on the political complexion of any particular state, nor on the very loose concept of the 'extreme emergency exemption', but on the violation of the rights of states (e.g. sovereignty and self-determination) which international law has recognized as pertaining to all. In such a world, no single state possesses the capacity to rightfully judge others, unless such judgment involves the breaking of a universally accepted law of the community of nations. Intervention, or a just war, will also become a matter of a defense of fundamental rights, which means recognition not of the virtue of any given political doctrine and system, but of the inherent worthiness of individuals regardless of the regime under which they live. To this extent liberal regimes, in principle, may also be subject to universal judgment when and if they violate international humanitarian law or when and if they promote, in some manner or other, human rights violations. Rawls's work, of course, does not see liberal democracies as being subject to such sanctions because the point of departure of his book assumes that such violations are, in principle, not likely or not part of a kind of social order conducive to validating them.

It is also the case that Rawls's conception of human rights in liberal regimes does embrace a host of rights which Vitoria would consider as natural rights, that is, as rights which defend the essential dignity of man. However, the appeal to democratic constitutional government and property ${ }^{72}$ as constituting part of those essential human rights tacks on too many "rights" (i.e. political and economic), which, in Vitoria's thought, would seem arbitrary. Rawls's position on property, for example, is quite possibly inspired (since much of his thought is based upon Kantian philosophy) by Kant's conclusion that the possession of property itself is a moral law accepted by all. In this view, Rawls's propositions, which elevate to the rank of a natural (human) right particular political and economic arrangements, are arbitrary and culturally specific assessments of the natural character of man, and are drawn upon as a set of criteria for judging other societies. Such criteria, from the perspective of Vitoria's conception of natural right, have no bearing upon the essential rights of individuals since the latter are pre-political and thus transcend all contingent forms of social organization. The "truthfulness" or universal quality of a natural right in Vitorian thought will, by contrast, be expressed

The UN Human Rights Declaration does establish the electoral process as a right of peoples in the choosing of government representatives, but this is not the same as setting forth liberal constitutional government, and the economic philosophy that invariably accompanies it, as a world standard of legitimacy.

72 Rawls, The Law of Peoples, 65. 
in general, but not specific, terms. As Neumann suggested, "whenever Natural Law doctrines deduce elaborate systems with political and social postulates (whether it be private property or socialism) they are arbitrary and have no validity". ${ }^{73}$

To this effect, one should recall the Thomistic principle of natural law which states that good is to be done and evil to be avoided. The principles of justice, derived from the natural law, underscore equality and reciprocity among social agents as proper traits of a society that moves toward the common good. These represent natural right postulates bearing the highest level of generality that are obviously independent of particular prescriptions. A just social arrangement is one in which equality between agents is maintained without considering their personal condition, as Thomism's conception of justice and as modern legal doctrine maintain. In other words, a just order is one in which principles, but not the cultural preferences or values of agents, are brought to fruition.

It is important to note that the idea of natural rights in Vitoria's Thomism, broadly conceived, also places a premium on a general view of them. For example, they will be often be asserted by general concepts such as "the right to life", "liberty", or "human dignity" as fundamental propositions which are necessary for human flourishing. But such universal concepts do not make their corresponding and specific social arrangements universal. Precisely the idea of free-will or liberty is preserved in the ability of different societies to independently chose, as they must, the way they shall be governed, under what political and social conditions, and by whom. Whether they choose to be governed by one political system in lieu of another is of no consequence to this view of justice.

On the question of the preferability of one regime form over another, Vitoria's De potestate civili (1528) argues, "there is no less liberty under a monarchy than under an aristocracy or timocracy". ${ }^{74}$ Scholars like Pagden have taken this to only mean that Vitoria actually favored monarchy (which was true as a personal preference). But this entirely misses the point. Vitoria was actually taking a position on the proper role of political power in society. He saw political power as a natural phenomenon (in the Aristotelian sense) arising for the purpose of unifying society and of impelling it toward the common good and justice. "This power", he maintained, "is the same whether it be exercised by one man, or by whole community or commonwealth, or by the nobles; there is clearly no greater liberty in being subject to three hundred senators than to one king". ${ }^{75}$ This is because the legitimacy of the regime rests, in this view, on the realization of justice not on regime form.

The legitimacy of a regime will be judged, then, by the extent to which it preserves within its particularity these general principles (brought from potency to act by positive law), and not by its political character, which is ultimately, or ought to be, the expression of a conscious act of self-determination (also considered a natural right) articulated within the legal system of that particular regime. This notion is similar to the Thomistic 
conception of positive law as the expression or concretization of the principles of justice. The principles of justice and natural right will not vary; but the positive legal system and norms will, since each society concretizes such principles in a manner consistent with the particular needs and characteristics of its cultural and historical milieu. In this manner, Thomistic doctrine considers the diversity of legal systems as a necessary aspect of social life, essential to the realization of the principles of justice.

I would argue that it is for this reason that Fernando Tesón makes the following critical statement on the character of Rawls's law of peoples: "Rawls's international law principles do not even authorize representatives of liberal societies to publicly (that is, in an international forum such as the United Nations) criticize the non-liberal practices [...] For in Rawls's international system liberals could derive no argument from international law to make such a [public] criticism. They could do so only if the hierarchical societies failed to observe what Rawls calls 'basic' human rights, such as if they arbitrarily killed or tortured people or if public officials violated their own conceptions of justice" ${ }^{76}$ This is a crucial difference between the Rawlsian law of peoples, natural law and international law. The latter two are indeed concerned with fundamental human rights, the rights of states, the corresponding international legislation protecting them, and hence judge regimes on that perceived universal-legal basis. Vitoria's conception of natural right and international law, will have a critical bearing upon particular political systems only insofar as they violate rights expressly prohibited by law or ethical norms, but not insofar as they are "liberal-democratic", "socialist", or "theocratic". Rawls's law of peoples is indeed necessarily "political" in its propositions, rather than legal in any sense consistent with the historical development of legal doctrine, even its own.

Finally, Vitoria did also maintain that the world could not only generate laws for itself on the basis of majority consensus, but could equally elect a ruler (i.e. a particular system of governance). ${ }^{77}$ But such measures were to be taken, again, on a consensual or majority basis, and not by the political will of any particular state. The states-system could, consequently and theoretically, choose liberal democratic governance as a political standard, but this would be the outcome of voluntary choices to the same extent that the adoption of Christianity in the New World had to be the expression of unthreatened free-will. Furthermore, he saw the indigenous communities as being self-sufficient (as communitas perfecta and hence sovereign), composed of rulers, magistrates and laws. It was for this reason, and despite the 'barbarous' customs of many of these communities, that they could not be forcefully converted to Christianity, deprived of their possessions, nor justly warred upon unless their rulers committed great injustices against their people. ${ }^{78}$

In any case, from Vitoria's perspective, the Achilles heel of Rawls's Law of Peoples would be its ultimate and explicit political foreign policy aims and the manner in which it exempts

76 Fernando Teson, "The Rawlsian Theory of International Law", Ethics and International Affairs 9, No 1 (1995). Cited in Kok-Chor Tan, “Liberal Toleration in Rawls's Law of Peoples", Ethics 108, No 2 (1998): 282.

77 In De potestate civili (1528) maintained: "The human race", he maintained, "once had this power of electing a single supreme prince, in the beginning before the division [of races]; therefore, since this power was part of natural law, it must still exist". Pagden and Lawrence, eds., 31-32.

78 On this question see Vitoria's De Indis (1539) in ibid. 
itself from the requirements of the Christian just war doctrine (as Rawls himself admits, albeit quite uncritically). Both policy prescriptions thus ultimately dispense with the principle of equality between states and, in parallel fashion, are willing, when necessary, to sacrifice the rights of the innocent in the pursuit of a perceived "higher cause". In this view, the unshackling of power from ethical restraint, which is inconsistent with the prescriptions of natural right and international law, would create an order antithetical to both the Christian and secular conceptions of justice. Justice itself, as a broad category of theory and practice, would acquire, as in Rawls's conceptualization of the "just war", a wholly politicized definition.

\section{ORDER AND JUSTICE REVISITED}

The current literature on international affairs offers no unitary account of justice; and it is difficult for this reason to find anything similar to Vitoria's Thomistic doctrine. A notable exception to this, however, is Nardin's recent account of justice. His point of departure properly emphasizes the numerous and diverging interpretations in the literature (referring to what he rightfully deems "conceptual incoherence") and then poses what I view as a fundamental question pertaining to the field of moral enquiry in international affairs: "Which [moral] principles justify coercion? Which are so important that they should be turned into enforceable law?"79 This way of framing the question of justice is based on the idea that "political deliberation", as Nardin maintains, has as a primary aim the determination of those moral rules, of those rights and duties, binding members of an international community; rules which may be equally considered as falling within "the proper scope of international law" ${ }^{80}$ In this sense, Nardin is expressing the Vitorian idea that the community of nations has a right, if not a duty, to establish laws for itself for the maintenance of a just order.

But we must further understand what justice is within this framework of a community liable to generate laws of governance among states, and why this is so. Nardin proposes recovering a narrow sense of justice as entailing a right to use coercion in circumstances in which laws or institutions have become "deficient" in their operations. The Thomistic conception of justice in a similar respect sees the power of the state as being bound by specific principles because its purpose is to safeguard the general interests of society, or of the individuals that comprise it. Thus, power (especially political power) will be seen in two ways: a) as a moral faculty to govern, implying that such power is free and necessary to govern and exists for the benefit of society, but not for its own benefit; and b) it is, thus, bound by specific principles of justice (iustitia). ${ }^{81}$ In the first sense, it may claim a right that is proper to its governing role; and in the second sense, it is bound by duties which obligate it to implement power in a certain morally acceptable fashion.

79 Terry Nardin, "Justice and Coercion", in International Society and Its Critics, ed. Alex J. Bellamy(Oxford: Oxford University Press, 2004), 249.

$80 \quad$ Ibid.

81 Nardin similarly claims "A just state is one that succeeds in transforming morality into law and it is therefore of utmost importance that a state not enact laws that are contrary to morality". Ibid., 250-251. 
Now, just as the state may use coercive measures to enforce justice, so the international community may use coercion to enforce rules "to prevent some persons from using others coercively for their own ends". Nardin thus adds in referring to Kant: "As one interpreter of this tradition puts it, coercion is justified when it is 'a hindrance to a hindrance of freedom.'" ${ }^{\prime \prime 2}$

There are three interrelated elements operating in both Nardin's and Vitoria's thoughts on this matter that characterize the sphere of political life: power, justice, and man. The concept of man itself, and his essential worth, may be viewed as the basis upon which we consider the operations of the other two elements. The general argument would be that man bears a relationship with both these "orders" for he needs justice, as do his fellow men, in order to live in society since justice defines his rights and his duties. Justice, however, without power (or coercion, as Nardin would put it), is lifeless, as in Hobbes' view of law in the state of nature. And power becomes immoral if it bears no connection to justice. Justice, then, tells both man and power what should be done for the preservation of rights and duties. ${ }^{83}$ In this view, when power strays away from its proper role, other powers may justifiably restrict its operations and place it back onto the "correct" path.

Nardin rightfully stresses the idea that the concept of justice involves three elements. The first, like Thomism, involves the idea of the universality of its precepts, which supersede local morality, and thus the concomitant assertion that all rational human beings may know it. Secondly, justice is something social or relative to relationships between individuals in society. Thomistic doctrine similarly speaks of justice as that part of natural law (lex naturalis) pertaining to the social order. Third, justice he identifies with duty. "To be just to others is to give them 'their due'-that is, what is morally due to them and therefore what we have a moral duty to do (or avoid doing) to or for them. Justice is about actions that others have a right to expect from us, not merely those they would like us to perform, or that it would be good or desirable that we perform". ${ }^{84}$ The definition is virtually identical to the one in the Justinian Digest and which Aquinas and Vitoria take as their own: "the perpetual and constant will to render to each one his right $^{\prime \prime} .{ }^{85}$ The nexus between justice and coercion is thus related, Nardin holds in a manner similar to what I suggested in the paragraph above, to the idea that the abandonment of duties may justify the use of coercive measures in order to enforce compliance. It is characteristically difficult, however, to correctly determine the line separating permissible and impermissible coercion because often such determinations involve, in this view, problems of interpretive judgment of particular circumstances. The problem is similar

$82 \quad$ Ibid., 249.

83 In a more fundamental sense, justice is always directing men, whether we speak of "power" or of "man", for humans ultimately wield power. Power is hence a mere formal category used to designate the office of the sovereign ruler or magistrate and thus to make a proper distinction between those who are governed and those possess, as Vitoria might put it, political dominium.

84 Nardin, 250.

85 See, ST II-II, q.58 a. 1; and Francisco de Vitoria, La Justicia, ed. Antonio Truyol y Serra, trans., Luis Frayle Delgado, Clásicos de Pensamiento 147 (Madrid: Editorial Tecnos, S.A., 2001), 35. 
to the one posed by Catholic natural law itself. The magistrate is burdened with the question of interpreting and deducing precepts from general propositions. The process of knowing what these are involves not only education in the virtues but also a slow process of cultivating practical reason through experience and maturity, something similar to the qualifications seen as necessary for jurists of high rank in judicial courts.

In any case, Nardin's point is that the demands of this kind of morality, while universal in scope are nonetheless 'minimal.' They refer to principles that do not include notions regarding the "desirability" of other greater (or culturally defined) goods. They are equally distinguished from other notions of justice focusing on the need for economic equality and from other similar conceptions that link justice to charity. ${ }^{86}$ Common morality thus cannot enforce or espouse prescriptions that surpass its essential notion of justice, for this would mean entering into realm of peoples' personal choices. The concern then is with a core notion of man. Like Vitoria's view of justice, it is more associated with what we would call fundamental human rights applicable to and recognizable by all human beings. ${ }^{87}$ When these are violated coercive force may be employed. Nardin sums up the substance of his argument in the following manner.

Justice, then, entails the right to use coercion. And the moral basis of this right should by now be clear. Human beings are thinking, choosing beings -'agents', in the jargon of philosophy- and if they are to exercise their agency they need to be protected against interference with that exercise. They have the right to defend themselves against force and fraud. They also have the right to live under laws that protect them from being used, against their will, to satisfy the wishes of other human beings. In civil societies the right to use coercion to defend one's rights or the rights of others is transformed into the authority of the state to defend individual ('natural' or 'human') rights. Coercion by the state, through the medium of enacted and effective law, is morally justified to protect those rights. Finally, where the state is tyrannical, where its laws are unjust, people may be justified in coercively defending themselves and others against violations of their rights. The casuistry required to work out the implications of these principles in particular situations is necessarily complex and contested. But, speaking philosophically rather than practically, this is the moral logic of 'justice' in human affairs. ${ }^{88}$

Nardin's 'image' of the world, as with Vitoria's, is composed of both humans and states; and is therefore "a community of human beings with human rights and of states with sovereign rights". ${ }^{89}$ The legitimacy of states will thus be measured by the extent to which

Nardin, 257; ibid. Aquinas thus distinguishes justice from charity: “The Philosopher (Ethic. viii) does not deny that friendship is a virtue, but affirms that it is 'either a virtue or with a virtue.' For we might say that it is a moral virtue about works done in respect of another person, but under a different aspect from justice. For justice is about works done in respect of another person, under the aspect of the legal due, whereas friendship considers the aspect of a friendly and moral duty, or rather that of a gratuitous favour, as the Philosopher explains (Ethic. viii, 13)". (ST II-II, Q. 23 a. 1).

87 Ibid., 251; ibid.

$88 \quad$ Ibid., 255.

89 Ibid., 256. 
they uphold and defend the essential rights of individuals. Intervention will thus be forthcoming, and the principle of non-intervention and sovereignty forfeited, when these rights are violated. This argument likewise considers such intervention, as did Vitoria on the question of human sacrifices in the indigenous communities of the New World, a duty to be performed. "In other words", Nardin maintains, "the non-intervention principle, which derives from the idea of state sovereignty and is part of the institutional structure of the states-system, here gives way before the natural duty of assistance to those who are victims of atrocity and whose situation is desperate".$^{90}$ The principles of justice apply equally to relations between states and thereby uphold the restrictions of the ius ad bellum and the ius in bello. What is substantially reproduced here, then, is the Vitorian conception of the world as composed principally of individuals who have, nevertheless, organized themselves into independent communities. Their political separateness has not, however, dissolved their natural and essential ethical nexus. And it is that nexus, expressed as justice (that framework of rights and duties among individuals and communities), which either restricts state power or authorizes the use of force in circumstances of injury.

Nardin's conclusions are hence wholly compatible with the Vitorian conception of justice: 1) they are both "rational reconstructions" of principles that are binding upon all communities and discoverable by all. Their prescriptions thus encompass only those principles that all peoples may share; but they do not make prescriptions that go above and beyond the moral particularities of each community. "People may choose to live a Christian life, for example, but common morality does not require that they make that choice,","19) from this it follows that both are "coherent and robust" systems that dispense with particularist claims of universality (they thus reject utilitarian and realist formulae in their essential rejection of the equality among individuals and mutual respect);3) they also reject the idea that "international morality" and personal morality are antithetical notions. They thus dispense with the other Realist claim that the principles of morality cannot be applied to the anarchical and immoral world of international politics. It is precisely here, it may be argued, where these principles should be applied; 4) they both argue that a state may legitimately enforce only those laws or principles pertaining to these conceptions of justice.

More demanding moral practices, as Nardin maintains, may be enforced locally upon individuals who have voluntarily chosen to be members of that particular community. And this is identical to Vitoria's claim that those converted legitimately to Christianity would fall under the jurisdiction of a Christian prince and, by dint of logic, the Church,92 $5)$ to this extent, both views underscore the continued relevance of international society, for this points to the persistence of the idea that individuals live within a diversity of states; and this is seen as both an empirical reality and one which also is deemed necessary for human flourishing within a manifold system of sovereign communities. ${ }^{93}$

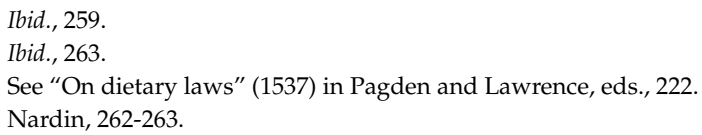


Nardin thus rightly notes, "The central tension in international society is not between order and justice but between just and unjust coercive orders" ${ }^{94}$ This is tantamount to saying, then, that a more viable kind of order is not predicated upon political definitions of it but rather on the vitality of the principles of justice underpinning it.

Bleiker's position is similarly correct in emphasizing that the idea of order in international politics may imply a condition of power-political arrangements that arises and exists independently of the principles of international law and institutions. ${ }^{95}$ This means that order will then point to a state of affairs in which unrestricted power disobeys fundamental principles of coexistence in an attempt to imprint upon international society its particular view of the world by unjust coercive means. This will be an order of particularism expressed in universal terms; a particular set of values professed in a language of apparent universality. By contrast, in Vitoria's tradition and in the position held by Nardin, order is a function of the extent to which the power of the Leviathan is rightfully contained and deployed, its duties and rights defined. This means that justice is but a form of order that simultaneously restricts power and directs its impulses towards its "natural" ends conventionally seen as the common good and the advancement of individual and collective human flourishing. That end, according to this view, defines the limits to, and the objectives of, state policy and political activity. Restriction and direction are thus its keynote features. In other words, the core attitudes describing state legitimacy in both cases stem from the state's capacity to articulate a kind of fundamental justice conducive to social peace and human fulfillment. A legitimate international order, finally, can been seen as a culturally and politically diverse community of just states upholding and enforcing justice both within the confines of domestic society and in their mutual relations. Politics, in this view, is primordially and fundamentally at the service of justice.

\section{JUSTICE IN THE ‘REAL WORLD’?}

The implementation of this kind of justice would ultimately require the inception of at least two global social processes. First, the gradual creation of an authority (or series of authorities) with sufficient jurisdictional power to make justice observed. This statement is easily taken as idealistic in its aims. State practice demonstrates, it may be argued against this position, how such idealism is trapped in the cage of its own utopia. But this criticism bears no relation to the world of possibility, and it is philosophically a sound doctrine however difficult its realization may seem. The idea of justice, as claimed Wight when referring to Christian pacifism, is a "long-range policy" ${ }^{96}$ It is something that is slowly achieved by human learning and volition, but not a given. The requirement of an authority is similar to the idea of a naturally existing power regulating national life, as

Ibid., 263.

Bleiker, 182.

Martin Wight, "Christian Pacifism", Theology: A Monthly Journal of Historic Christianity XXXIII, No 193 (1936): 21. 
in the Thomistic and Aristotelian theory of the state. The absence of a governing agency within the realm of the state, Vitoria maintained, would lead to the wills of individuals moving in divergent directions, tearing apart the fabric of social life. As Nardin put it, "a society needs rules for reconciling our divergent wills" ${ }^{97}$ This latter view of the state without a system of rules, but enforced by a governing authority, is substantially the anarchical view of the states-system marked by the "disorder" of anarchy and the reliance on mechanical balances, in the absence of justice. While Vitoria did not speak of a supranational authority as a natural phenomenon, it was clear to him that the totus orbis could elect a higher authority and also dictate laws for itself. It is thus a tribute to this idea today that international society, as one scholar contends, has increasingly moved toward a more solidarist conception in many quarters. ${ }^{98}$ There is, according to such views, a possibility that order become a function of a growing political culture that is developing a shared understanding of justice ${ }^{99}$ in which international order may likewise be seen as an expression of growing "shared identities" in an era of globalization. ${ }^{100}$

Finally, from this it follows that a political culture enshrining such values as human rights and justice requires "education in the virtues", to use Thomistic terminology, or the reliance on a "sentimental education", as Rorty argued. ${ }^{101}$ This means keeping in check the Hobbesian image of the world as the standard by which policies are formulated, and embracing more humane paradigms that underscore the value of the individual, and individual choice, as the criterion upon which political society, national or international, is justified.

\section{CONCLUSION}

Since the rise of modern ideological politics, international relations have been historically shaped by differing views about the principles that should underpin international order. Ideology persistently moves to define the name and nature of that order in the language of political statecraft. Whether we speak of the attempts by Fascism to base such relations on violent racial principles, or of the post-war struggle for hegemony between Soviet communism and liberalism, the present post-Cold War international order is "the fruit of a predominantly western political tradition", which is tantamount to saying that order and legitimacy have been a function of particular Western views about the balance of power (i.e. about the structure of interstate relations) and about the internal political complexion of states seen as sources of threats to that balance or status quo of power relations at any given point in history. To this extent, legal doctrine and

$97 \quad$ Nardin, 254.

98 Andrew Hurrell, "Order and Justice in International Relations: What Is at Stake?", in Order and Justice in International Relations, ed. Rosemary Foot, John Gaddis, and Andrew Hurrell(Oxford: Oxford University Press, 2003), 32.

$99 \quad$ Ibid., 41.

100 Bleiker, 182.

101 Tim Dunne and Nicholas J. Wheeler, eds., Human Rights in Global Politics (Cambridge: Cambridge University Press, 2001; reprint, 1999), 9. 
law, which attempt to regulate state conduct, have also often been subject to reproach by ideological belief systems as when German National Socialism rejected that states could be subjects of international law, or when, similarly, liberal international lawyers blamed the chaos of the period on "unlimited" state sovereignty. ${ }^{102}$ Each has sought to amend law or to subject it to its political imperatives thus defining order and legitimacy in such terms.

The foregoing discussion has essentially argued that the ascendancy of politically determined legitimacy, in practice and theory, fosters conditions of over-contentious and conflict-prone relations, which also weakens the traditional legal framework underpinning international relations. Some have seen as a consequence a manner of polarization between Western and non-Western states as well as the emergence of autocracy as a possible response to forms of democratic promotion perceived ultimately as "simply extensions of Western state power, and ways of exploiting and perpetuating the imbalance of power that the end of the Cold War had inaugurated" ${ }^{103}$ Backed by methods that legitimize the straying away from customary legal norms, this process becomes, in a sense, an instance for the degradation of law by the requirements of political expediency. This was the attitude similarly describing Machiavelli's outlook and that of the Italian doctrine of Reason of State, both of which repudiated ethics, particularly Christian ethics, as a sound guide for statecraft in a hostile, power driven milieu. The Spanish Crown, too, appealed, in practice, to this doctrine as it sought to create a religious order of legitimacy (though the term 'legitimacy' was not yet in currency) and political uniformity. The work of pro-imperial theologians such as Juan Ginés de Sepúlveda, who attempted to justify the use of force on this basis, however, met with the opposition of the 'theologian-jurists'. The ethical debate that ensued produced the Spanish intellectual contribution to international law, which sought to predicate relations on a juristic or moral understanding on the limitations to state conduct. ${ }^{104}$ Justice and the resulting order of peace was its final aim. ${ }^{105}$

Likewise, the democratic peace thesis and its philosophical underpinnings have articulated similar 'Realist' assumptions centering on security and the need for a politically based order of peace. The argument for the expansion of democratic principles has been cogently argued. The core idea is that democracy and its peace thesis is now, in fact, an integral part of international law in the sense of its pursuit of the "peremptory norm of global peaceability". ${ }^{106}$ The defense of human rights would thus become a function not merely of legal norms but obviously of political regime forms conducive to their defense.

Franz Neumann, Behemoth: The Structure and Practice of National Socialism 1933-1944 (New York: Oxford University Press, 1944), 167.

103 Clark 2009, 579, 581

104 For an overview of the ethical debate in Spain, see Ramos, Demetrio. La Ética en la Conquista de América: Francisco de Vitoria y la Escuela de Salamanca. Corpus Hispanorum de Pace. Madrid: Consejo Superior de Investigaciones Científicas, 1984.

105 Hanke, Lewis Ulysses, and American Historical Association. The Spanish Struggle for Justice in the Conquest of America. Philadelphia: University of Pennsylvania Press, 1949.

106 Buergenthal, T., "The Normative and Institutional Evolution of International Human Rights", Human Rights Quarterly 19, Nº 4 (1977): 714-15, cited in Clark (2009): 571. 
This has also been accompanied by institutional support through, for example, a United Nations advocacy of human rights (and the support of such rights in other covenants) and by the favorable position of power of the United States, which could conceivably secure the vitality of such norms. ${ }^{107}$

The Rawlsian position, I argue, is a kind of philosophical defense of this attitude whose noble aspirations are marred, however, by its appeal to the 'supreme emergency exemption' that makes its philosophical outlook unviable and incoherent. Unviable because its policy of global transformation is ultimately at variance with global regime diversity. The linchpin of that policy is the statement that liberalism must examine to what extent it will 'tolerate' non-liberal peoples coupled with a back door, exceptional recourse to extra-legal means of intervention and violence. The question then is whether a politically determined order of this kind is preferable to a more minimalist conception of order that does not slip political ideals into its view of world peace.

Incoherent because its view of democracy, while consistent with the current human rights conventions, lays devastation to itself by allowing for the implementation of means that destroy the very rights it presumably seeks to uphold. It does this by sanctioning the use of violence against the innocent and by subduing the element of personal choice in a society's determination of the kind of government over which it may elect to be ruled. The question remains whether politically this policy of ends and means can become, in practice, and not merely in theory, a foundation for peace in international affairs.

I suggest that Vitoria and Nardin's 'minimalist' views of justice are more sound standards of legitimacy and more conducive to peace because they appeal, at bottom, to both human dignity and to the exercise of individual and collective free will in matters of politics. The recourse to force is sanctioned only by the violation of such fundamental rights while the laws of war still remain as tenets that govern the conduct of war itself. To this extent they are equally more inclusive and tolerant conceptions of human society and of international society because they, likewise, appeal to long standing ideals of social life that have been the inspiration for political and legal philosophy in its aim to build and secure human flourishing. Unlike many of those philosophies, however, they are not dependent on, nor espouse, a particular political form nor indulge in the expansion of ideology as a cornerstone of peace and order. This is so, because they uphold the idea of human dignity, while the natural human rights pertaining to that dignity are judged as the ultimate source of legitimate political activity and the raison d'etre of the state, whatever its form is now and may become in history.

\section{REFERENCES}

Anderson, Chandler P. 1934. "Recognition of Russia". American Journal of International Law 28, No 1: 90-98. Anderson, Perry. 2005. "Arms and Rights". New Left Review 31: 5-40.

Beitz, Charles R. 2000. “Rawls's Law of Peoples”. Ethics 110, No 4: 669-696. 
Bleiker, Roland. 2004. "Order and Disorder in World Politics". In International Society and Its Critics, edited by Alex J. Bellamy, 179-192. Oxford: Oxford University Press.

Booth, Ken. 2001. "Three Tyrannies". In Human Rights in Global Politics, edited by Tim Dunne and Nicholas J. Wheeler, 31-70. Cambridge: Cambridge University Press. Reprint, 1999.

Brown, Chris. 2002. Sovereignty, Rights and Justice: International Political Theory Today. Cambridge: Polity Press.

Brown, Philip Marshall. 1932. "The Recognition of New Governments". American Journal of International Law 26, $\mathrm{N}^{\mathrm{o}}$ 2: 336-340.

Buergenthal, T. 1977. "The Normative and Institutional Evolution of International Human Rights", Human Rights Quarterly 19, $\mathrm{N}^{\circ} 4$.

Bukovansky, Mlada. 2009. Legitimacy and Power Politics: The American and French Revolutions in International Political Culture. Princeton: Princeton University Press.

Clark, Ian. 2003. "Legitimacy in a Global Order". Review of International Studies, N² 29: 75-95.

Clark, Ian. 2009. "Democracy in International Society: Promotion or Exclusion?" Millennium: Journal of International Studies 37, $\mathrm{N}^{\mathrm{o}}$ 3: 563-581.

Dunne, Tim. 2005. "Liberalism". In The Globalization of World Politics: An Introduction to International Relations, edited by John Baylis and Steve Smith, 162-189. Oxford, New York: Oxford University Press.

Dunne, Tim and Nicholas J. Wheeler, eds. 2001. Human Rights in Global Politics. Cambridge: Cambridge University Press. Reprint, 1999.

Goodman, Ryan. 2009. "Controlling the Recourse to War by Modifying Jus in Bello". 2009 Yearbook of International Humanitarian Law.

Graham, Malbone W. 1934. "Russian-American Relations, 1917-1933: An Interpretation". The American Political Science Review 28, No 3: 387-409.

Haas, Mark L. 2005. The Ideological Origins of Great Power Politics 1789-1989. Cornell Studies in Security Affairs, Edited by Robert J. Art, Robert Jervis and Stephen M. Walt. Ithaca: Cornell University Press.

Hershey, Amos S. 1921. "Recognition of New Governments". American Journal of International Law 15, $\mathrm{N}^{\mathrm{o}} 1: 59-62$.

Hurrell, Andrew. 2003. "Order and Justice in International Relations: What Is at Stake?" In Order and Justice in International Relations, edited by Rosemary Foot, John Gaddis and Andrew Hurrell, 24-48. Oxford: Oxford University Press.

Ikenberry, G. John. 2000. After Victory: Institutions, Strategic Restraint, and the Rebuilding of Order after Major Wars. Princeton: Princeton University Press.

Kagan, Robert. 2007. Dangerous Nation: American Foreign Policy from Its Earliest Days to the Dawn of the Twentieth Century. New York: Vintage Books.

Kissinger, Henry A. 1977. A World Restored: The Politics of Conservatism in a Revolutionary Era. London: Victor Gallancz.

Luban, David J. 2010. "Opting out of the Law of War: Comments on 'Withdrawing from International Custom'". Yale Law Journal 120.

Mayall, James. 2000. “Democracy and International Society". International Affairs 76, No 1: 61-75.

Nardin, Terry. 2004. "Justice and Coercion". In International Society and Its Critics, edited by Alex J. Bellamy, 247-263. Oxford: Oxford University Press.

Neumann, Franz. 1944. Behemoth: The Structure and Practice of National Socialism 1933-1944. New York: Oxford University Press.

Neumann, Franz. 1957. "The Change in the Function of Law in Modern Society". In The Democratic and the Authoritarian State: Essays in Political and Legal Theory, edited by Herbert Marcuse, 22-68. Glencoe, Illinois: The Free Press.

Nys, Ernest, ed. 1917. Francisci De Victoria: De Indis et de Iure Belli Relectiones. Vol. 7, The Classics of International Law. Washington: Carnegie Institution of Washington.

O'Hagan, Jacinta. 2002. Conceptualizing the West in International Relations. Houndmills: Palgrave Macmillan. Pagden, A. R. and Jeremy Lawrence, eds. 1991. Francisco De Vitoria. Political Writings, Cambridge Texts in the History of Political Thought. Cambridge: Cambridge University Press. 
Rawls, John. 1999. The Law of Peoples. Cambridge, Mass.: Harvard University Press.

Rawls, John. 1999. The Law of Peoples: With "the Idea of Public Reason Revisited". Cambridge, Massachusettes:

Harvard University Press. Reprint, 2003.

Scott, J. B. 1934. The Spanish Origin of International Law: Francisco De Vitoria and His Law of Nations.

Scott, James Brown. 1934. The Catholic Conception of International Law. Washington.

Shaw, Malcolm N. 2003. International Law. 5th ed. Cambridge: Cambridge University Press.

Suganami, Hidemi. 2003. "Beyond the English School". In Annual Convention of the International Studies Association. University of Birmingham.

Tan, Kok-Chor. 1998. "Liberal Toleration in Rawls's Law of Peoples". Ethics 108, N 2: 276-295.

Teson, Fernando. 1995. "The Rawlsian Theory of International Law". Ethics and International Affairs 9, No 1.

Valenzuela-Vermehren, Luis. 2011. "Ideology and Political Order: A Short Intellectual History with Implications for the International".

Vincent, RJ. 1980. "The Factor of Culture in the Global International Order". Yearbook of World Affairs 34: 252-264.

Vitoria, Francisco de. 1991. "On the Law of War (De Iure Belli)". In Political Writings, edited by A. R. Pagden and Jeremy Lawrence. Cambridge: Cambridge University Press.

Vitoria, Francisco de. 2001. La Justicia. Translated by Luis Frayle Delgado. Clásicos de Pensamiento 147. Edited by Antonio Truyol y Serra. Madrid: Editorial Tecnos, S.A.

Walzer, Michael. 1977. Just and Unjust Wars. 3rd ed. NewYork: Basic Books.

Wight, Gabriele and Brian Porter, eds. 1991. International Theory: The Three Traditions. New York: Holmes \& Meier.

Wight, Martin. 1936. "Christian Pacifism". Theology: A Monthly Journal of Historic Christianity XXXIII, $\mathrm{N}^{\circ} 193: 12-21$.

Wight, Martin. 1966. "Western Values in International Relations". In Diplomatic Investigations: Essays in the Theory of International Politics, edited by Herbert Butterfield and Martin Wight. London: George Allen and Unwin.

Wight, Martin. 1977. "International Legitimacy". In Systems of States, edited by Hedley Bull, 153-172. Leicester: Leicester U.P. in association with the London School of Economics and Political Science.

Luis Valenzuela-Vermehren. PhD International Relations (The London School of Economics \& Political Science). Magister Ciencia Política (Pontificia Universidad Católica de Chile). BA Political Science (University of California at Berkeley). Profesor Asistente del Departamento de Sociología y Ciencia Política de la Universidad Católica de Temuco.

Líneas de investigación: Teoría de las relaciones internacionales, política exterior de las grandes potencias, ideología y política internacional.

E-mail: lvalenzuela@uct.cl. 